\title{
Beliefs Worship the Village's Tutelaray God in the Beliefs Life of Vietnamese People
}

\author{
Vu Hong Van \\ Department of Basic Science, University of Transport and Communications, Hanoi, Vietnam \\ Email address: \\ vhvan@utc2.edu.vn

\section{To cite this article:} \\ Vu Hong Van. Beliefs Worship the Village's Tutelaray God in the Beliefs Life of Vietnamese People. Humanities and Social Sciences. \\ Special Issue: Religion, Gnosticism and Spirituality. Vol. 7, No. 5, 2019, pp. 150-158. doi: 10.11648/j.hss.20190705.12
}

Received: July 9, 2019; Accepted: August 28, 2019; Published: September 20, 2019

\begin{abstract}
Vietnam is a country with many beliefs and religions, including beliefs and religions imported from abroad, but there were also beliefs that appear on Vietnam itself. We can refer to typical folk beliefs such as: worship ancestors, worship of Mother Goddesses and many other typical folk beliefs, in the worship of the Vietnamese, beliefs worship "Thành Hoàng làng" (the Village's Tutelary god) is one of the popular beliefs throughout the country. In villages of Vietnamese and communes, the beliefs worship Village's Tutelary god is a sacred belief, a spiritual support for village communities for generations. Through the ups and downs of the times, the beliefs worship the Village's Tutelary god had many changes, however, along with other folk beliefs, the belief of the Village's Tutelary god has played an important part in creating the characteristic of beliefs and the culture of Vietnam. This analysis will join us in answering many questions related to the worship of the Village' Tutelary god, namely: What is the Village's Tutelary god? Why was the Village's Tutelary god not the Tutelary god? Why have had there a worship of the Village's Tutelary god in Vietnam? Beliefs of the Vietnamese people into the Village' Tutelary god, the position of the Village's Tutelary god in the religious life of Vietnamese people.
\end{abstract}

Keywords: Beliefs, Worship, Village's Tutelary God, Life, Vietnamese, People

\section{Introduction: Problem and Methodology}

Vietnam is a country with many beliefs. One of the most popular beliefs of the Vietnamese nation in all parts of the country from North to South is the belief of worshiping the Village's Tutelary gods in the villages. The Village's Tutelary god is worshiped in village communal houses and is highly revered by the villagers. In the national beliefs system of Vietnam, the belief of worshiping the Village's Tutelary god has become an indispensable part of the spiritual life of Vietnamese people. The belief of worshiping the Village's Tutelary was born from the tradition of "drinking water, remember the source" of our people with gratitude, promoting the role of people with meritorious services to the people and the country.

In traditional customs of Chinese people, the Tutelary god was the protector of the stronghold, from the central to local levels. The Tutelary god defended the bureaucracy and the inhabitants of the city. Outside the citadel, Chinese people did not worship the Tutelary god. But it was god, so the Tutelary god could also create rain, create wind, protect good people, punish bad guys, educate and trial... In the Chinese imperial religion, secular tendency was quite strong. The Tutelary god became the lord of the town's underworld. The Tutelary god had a "superior", and had a "subordinate", clearly demonstrating the authority of the leader.

In Vietnam, in every family, Vietnamese people worshiping ancestors, Mother Goddess worship and some and some other folk beliefs. "The most popular Vietnamese people, the most prominent is worshiping gods in the village, no village is without a temple and shrines" [1]. In the villages, Vietnamese people worshiping Village's Tutelary god. The Village's Tutelary god is a common noun to refer to a god worshiped in a Vietnamese village. Like Tao Cong, Tho Cong and Than Tai, the Vilage's Tutelary god ruled and decided the blessing of a village and was often worshiped in the village communal house. Therefore, almost every village or street (where the city is) establishes a communal house (or temple, shrine) to worship the Village's Tutelary god of the village or guild. The Village's Tutelary god was a man who 
with meritorious services to the people and the country. Thus, "The Village's Tutelary god is the most sacred symbol of the whole village, in every village, throughout the old villages" [1]. The worship the Village's Tutelary god in Vietnam was due to the influence of Chinese culture that was transmitted from the Tang Dynasty. However, according to Phan Ke Binh, "before that, our people also had folk beliefs. After being introduced into the Vietnamese village, it quickly became rooted in Vietnamese farmers's minds and was became very diverse, expressing the tradition of "drinking water to remember its source" [2].

The worship of the Village's Tutelary god is a psychological need, people worshiping Village's Tutelary god to serve the real life, a spiritual support that is indispensable, a means and a method force for production and to settle down. People with meritorious services to establish villages, build hamlets or found a profession (the ancestor of the profession), and publicize the village and commune, after being killed, are worshiped by the people. The worship of the villlage's Tutelary god like the ancestors worship and the Mother Goddess worship which is deeply imbued with spiritual imprints and expresses the concept of "drinking water to remember the source" of the Vietnamese people.

Today, along with the changes of modern society and the changes in the perception of people, as well as many popular beliefs other, the Village's Tutelary god worship have also made changes to suit the new scene. However, the values of this belief still exist and has been becoming the source of Vietnamese culture.

The author was born and raised in rural areas of Vietnam, since the early age, the author has witnessed many village festivals, rituals of the people in the village. Especially on traditional holidays and Luna, the villagers gather a great deal in the communal temple to pray, pray, ask for blessing, pray for peace, pray for peace, the family is lucky, the children are busy, they are lucky, expensive sale... These activities follow very long, sometimes even a month. In the center of the village communal temple, there is the village of the Village's Tutelary god that is highly revered by the people.

When growing up, choosing careers, the authors chose to study philosophy and religion, thus having conditions to further study those rituals. In order to search for materials for their articles, the authors in addition to studying ancient bibliographies also conducted field surveys in many localities, participated directly in rituals to worship the village's Tutelary, studying, surveying village houses that exist today in Vietnam and interviewing people in rural villages and communes on all the North - Central - South regions of Vietnam. Based on this understanding of this folk belief, as well as the research results on the worship of Village's Tutelary god of Vietnamese people, the authors embarked on researching the topic: Beliefs worship the Village's Tutelaray god in the religious life of Vietnamese people.

\section{Folk Beliefs and Beliefs of Vietnamese People}

\subsection{Beliefs of Vietnamese People}

Beliefs and religions are a kind of social consciousness, reflecting in a wild and unrealistic way of reality. All religions and religions are nothing more than a virtual reflection in people's minds, like Engels: "religion is nothing more than a virtual reflection - in the minds of people - of outside forces that dominate their daily lives; it is just a reflection in which earthly forces take the form of supernatural forces" [3].

According to Dang Nghiem Van: "the term of belief can have two meanings. When it comes to religious freedom, foreigners can understand it as general belief (belief, lelieve, croyance) or religious belief (belief, believe, croyance riligieuse). If understanding belief is a belief, there is a part outside of religion, if it is understood as religious beliefs (belief, believer in the narrow sense croyance riligieuse) then belief is only the most essential component of religion" [4]. Some other researchers such as Phan Ke Binh [2], Phan Ngoc [11] and Toan Anh [6] consider beliefs as folk beliefs with worship rituals expressed through traditional festivals, customs and traditions of Vietnamese people.

In Chinese-Vietnamese dictionary, Dao Duy Anh explained: "belief is a superstitious admiration for a religion or a religion" [5]. In addition, there is a view that: beliefs synonymous with spirituality (spiritual beliefs) also mean that spirituality is not religion, spirituality is only the ability to lead to religion. Or belief is a form of social consciousness, a need of society and once those needs are not completely satisfied with the forms of social consciousness, for some social classes, Religion-belief is still the source of value, consolation, psychological support.

Vietnam is a country with many ethnic groups, many religions and different types of beliefs. However, since the formation, Vietnamese culture has been united, but there are still cultural characteristics of each ethnic group living on the Vietnamese territory, marking the difference between this ethnic group with other people.

\subsection{Folk Beliefs of Vietnamese People}

Folk beliefs are understood as primitive religious forms, they are formed on the basis of souls to realize reality and influence reality by means of (magical measures).

Using the term "folk belief" is to distinguish the orthodox beliefs and religions of the societies that have had the state (before the state, there is no distinction between folk culture and literature of the ruling class, there is no discrimination between folk beliefs and orthodox religion). Here, the author wants to clarify, the threshold of folk is a religion belonging to the popular class in society, different from belief, orthodox religion of the feudal state set up and managed.

A Western scholar, Patrick, B. Mullen argues that folk beliefs have a very rich and authentic inner meaning, "folk belief is a great genre that includes expression and behavior. 
we call superstition, popular beliefs, spells, supernatural phenomena, old housewives, folk medicine, folk religions, manifestations of weather, plants, words pray for recitation, people or things that carry risky things, things made from roots, good omen or bad omen, demons and taboos" [7].

As a starting point, Vietnam is an agricultural country of wet rice cultivation, with a rich and diverse indigenous culture that is largely formed from the life and activities of the working people, so it cannot be not interested in folklore in general and folk beliefs in particular, it is considered as the property of the people who work and are transmitted and stored through many generations of Vietnamese people, exist Parallel to the cultural and religious forms developed and promulgated by the state. Therefore, traditional beliefs are an important form of belief, popular in the cultural and spiritual life of our people for many generations, and even it is frequently valued and respected by Vietnamese feudal states and receive.

\section{Tutelary God and the Village's Tutelary God}

\subsection{The Tutelary God}

In the name Chenghuangshen, the first character cheng means "city wall" (a "defensive rampart"; or, by extension, "walled city") and the second character, huang, literally means "moat". Shen means a god. Put together, Chenghuangshen was originally the name of a deity or type of deity believed to be able to provide divine protection to a city's physical defenses, particularly its surrounding wall and moat. Later the concept became more generalized, and the meaning extended to the office itself of such a deity, rather than the presumed office-holder (in later times, it was standard to officially appoint the spirit of the government official in charge of the city to a three-year term as City god - Tutelary god) [8].

The term "Thanh Hoang" (Tutelary god) is a SinoVietnamese word. "The Tutelary god became a moat, a moat with water called maintenance, no water called royal. Applying soil as "city", digging trenches as "royal" [9]. "The name of Tutelary god of China that used in the sixth century to refer to the god of a city, and this institution was established by the Feudal dynasty" [10]. "This the custom of Tutelary god worship had the Three Kingdoms life, but in the old days, the King had a job of praying for islands and worshiping people. In the Tang Dynasty, Ly Duc Du (King) became a new general to start a royal temple in Chengdu, next to the Tong Dynasty, the Ming Dynasty was make temples and shrines anywhere" [2].

Through this understanding, the Tutelary god was a divine category which was responsible for protecting the stronghold of China's centralized feudal regime. Much as the ancient Indians and the ancient Greeks, the Chinese traditionally believed that guardian gods watched over cities. The Tutelary god was believed to be involved in communal concerns such as the need for rain, and may be involved in personal requests such as recovery from illness. Town residents may appeal to the Tutelary god for help in a natural disaster or other crisis. The Tutelary god could also be called upon to help those who are accused of crimes. The accused appear before the god and ask for a sign to help prove their innocence [11].

\subsection{The Village's Tutelary God}

Historically, Vietnam was an independent country. During the period from 46 (after the defeat of the Hai Ba Trung uprising) until 938 (Ngo Quyen's victory on the Bach Dang River), Vietnam was a colony of Chinese feudal dynasties. (Vietnamese people often refer to the Northern domination period). Along with territorial invasions, the feudal armies would inevitably carry with them religious beliefs. Therefore, the spread of Chinese beliefs and religions to Vietnam is evident. According to many researchers of Vietnamese folklore, Tutelary god beliefs can be propagated into Vietnam from the Tang Dynasty, and in particular the time is difficult to determine accurately. However, before foreign cultural factors (including Chinese culture), Vietnam had many folk beliefs with profound indigenous elements.

Also need to add, in Vietnam during the Northern domination period (the period when the country was dominated by Chinese feudal dynasties), there was also the Chinese model of the Tutelary god: "Ly Nguyen Gia built La Thanh in 823 to build To Lich temple is a Tutelary god" [12]. "In 866 Cao Bien expanded to become the Calendar of the Citadel as Do Phu Thanh Hoang Than" [8, 12].

Later, through the independent feudal dynasties of Vietnam, the Chinese model of the Tutelary god still exists: in the Ly dynasty, "In 1010, Ly Thai To left Hoa Lu capital to Thang Long, and re-named To Lich god to become Thang Long Citadel of Lord of Tutelary god" [11]. In Viet dien $u$ Linh, the spirit also added two gods with the form of Chinese Emperor: First, Khai Thien Tran Quoc Trung Phu Ta Duc Dai Vuong, who had the power to help Le Ngoa Trieu king (1006 - 1009) rule should be ordained was great Tutelay god (King of the Tutelary) $[12,13]$. Ly Thai To king relocated the capital to Thang Long, the fortification of the fortress was in trouble and the spirit of spirituality helped the king become a Tutelary god for Thang Long citadel people to worship [8]. In Tran dynasty added many beautiful words such as Quoc Bao, Hien Linh and Dinh Bang for To Lich. By the year of the first Huizhou (1285) (Tran dynasty) was named the Heavenly Emperor of the Royal City; second, Phu Ung Dai Vuong Loi Thanh Vuong, the god of merit protecting Dai la citadel, destroying the enchantments of Cao Bien [13].

By the Le dynasty, the worship of devils was in vogue. But, if you consider intentionally before, each region had the name of paint, great cross, the court established a shrine to worship the god of the cross to be the master of the monks. After the royal court, the middle-ranking monks and those who had merit to work with the country also set up temples for the people who lived near the church. Since then, the people had to imitate each other, every place had to worship a person to master the village. Any village with a proud hero who died will worship him immediately. If the village did not 
have hero, go and pray for another god to pick it up and worship it. "Or where the employees dream, divination, adoration, believe is a hunch that worship. Or where it is for a random, supposedly sacred, to ask for a sign to worship. Every village has a temple, every commune has a temple. Even newly established communes, first of all think about worshiping god" [12].

"The Tutelary god is derived from the base of Southeast Asian beliefs but has reverted to the Chinese style, according to court rules and the role of Confucianism is to institutionalize a familiar belief rather than to eliminate it replace it with another faith" [14].

Thus, the worship of the Tutelary god was introduced into our country according to the chronology probably from the Tang dynasty (China) and continued to develop in the independent dynasties of Vietnam later. After that, it was institutionalized according to the familiar beliefs of the Vietnamese people and entered the religious life of the Vietnamese village, the heroes of the village were worshiped by the villagers and offered to the imperial court. The god of ants, those heroes became the Vietnamese Village's Tutelary gods. Deity was a regular work of Vietnamese feudal dynasties. The spirit of the god was the spirit of the gods, there were many kinds of gods in the gods and one of them was the Village's Tutelary god.

\section{Discriminate the Tutelary God and the Village's Tutelary God}

Through the above analysis, we see that there existed two systems of the Tutelary god: the Chinese-style Tutelary god and the Vietnamese Village's Tutelary god. Chinese style Tutelary gods were inhuman, unidentified, non-originated, military functions to protect the city and the city. The Vietnamese Village's Tutelary gods were gods with origins, names and functions that govern and protect a Vietnamese village and commune.

Chinese feudal society was divided into two levels: Emperor and king. The ruler of the entire country, the king governs an area, was regarded as a small kingdom, has a citadel and has surrounding villages. Therefore, to protect the citadel, there was Tutelary god; to protect the hamlet, there was an Tho Dia. The worship of the Tutelary god was popular throughout the vast country of China. Where the citadel was built, it was dug out there to worship Tutelay god. Those Tutelary gods were often given a temple or a title by the king. The Chinese feudal government took the worship of the Tutelary god to educate people.

The Village's Tutelary god was the Tutelary with a worldly background, both mundane and sacred, without military functions, primarily protecting the material life of the villagers. "A system of boldness near the Tang dynasty Ming: the system of the Tutelary nation, province and district. Those were the anonymous, supreme gods, without any human merit, not even an angel of the Chinese model. However, in some cases, this system was immediately
Vietnameseized as To Lich - a rational person - was conferred the title of Do Phu Thanh Hoang (Tutelary god of capital). The second system was the Tutelary god - the village, which was the subject line reflecting the nature of Vietnamese religious beliefs" [9]

Thus, after reviewing all the inner functions and forms of the Tutelary gods and the Village's Tutelary gods, we realize that the fundamental difference between the Tutelary god (China) and the Village's Tutelary god (Vietnam) is:

The Tutelary god (China) acts as a general to support the king's sound. Only the king and the Emperor in the imperial capital (Do Phu Thanh Hoang) represent the country. Do Phu Thanh Hoang belongs to the Chinese Imperial Citadel. In feudal rule, the king became the supreme being of the Tutelary gods. So there was no Tutelary god of the Tutelary gods.

The Villages' Tutelary god (Vietnam): holding the position of the god of the village, being used by the central court as a spiritual delegate to the king in the village. The village Tutelary had both villages and nationally but was basically a village. Therefore, in the new folk, the said "The king lost to the village rules" was just because of that. The Village's Tutelary was not nationally valid because it was considered a "king" of a village.

\section{Beliefs Worship the Village's Tutelary God of Vietnamese People}

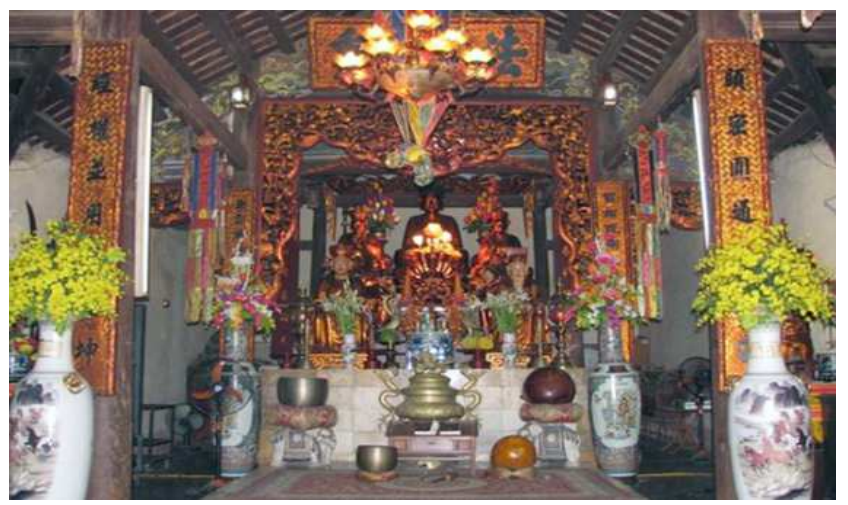

Figure 1. The Village' Tutelary god.

\subsection{When Did the Village's Tutelary God Appear}

Up to now, it have been difficult to have a specific document for the birth of the Village's Tutelary god. According to Nguyen Duy Hinh: "The date of birth of the Village's Tutelary god is difficult to identify. It can only be confirmed that it is time to form rural communes associated with the opening of the hamlet plain. That process began in the first millennium BC. The presence of many I Héger drums such as Ngoc Lu drums discovered in the old Ha Nam province, Co Loa bronze drum discovered in Co Loa, Huu Chung drums discovered in the old Hai Duong proves that Vietnamese people have gone to the plain around the 7th century BC. This chronology corresponds randomly to the Hung Vuong chronological record. But many villages were 
only born after the XV century. This is very important because it is the Le dynasty that controls the village base in a strict and comprehensive way of politics, economy and society" [9].

In the history of the development of Vietnamese feudal dynasties, since the Ly and Tran dynasties, "deity" was due to the "âm phù" of the god. But those gods only "âm phù" for the kings. During the period when Vietnam was invaded by the Ming Dynasty, according to the An Nam Chí book of Cao Hung Trung, the mandarin Minh followed the Chinese regime, setting up the Imperial Citadel in the province, Chau and districts of Vietnam [9, 20]. But starting from the Le dynasty, because of the Confucian monarchy, the central authority raised the right to exercise more power and authority, to seize all the power of the whole country into the hands of the court and govern the society to the village [1].

Therefore, mentally, "king" for the village god (to become the Village's Tutelary god head of the gods in the village), became a court official, a "king" on behalf of the local king "Classification" was the same as the regime of divination of feudalism. What was different, the task of the Village's Tutelary gods was to manage the "soul" of the villagers; while Ly Truong was responsible for managing the "corpses" of the villagers. Both of them - the Village's Tutelary god and Ly Truong had to leave home when working on the king. The communal house that became a minor court was like that. Most Emperors from the Hung Vuong era were retained when the independence regime of the nation was established. The dynasties still let the village worship the ancient Tutelary gods. It was only in the Le Dynasty that the god of the country was acquired in the hands of a head - that was the king [1].

The Le dynasty promoted Confucianism, but did not mean completely rejecting Taoism. The gods of Taoism are still worshiped in the sacred places such as Quan De, Huyen De, Van Xuong De Quan, Dong Nhac Dai De, La To, Thien Hau (Ma To). These inns were built by the king or the mandarins in the districts of Chau district and smoke all year round. The shrines had large and small gods such as Long Vuong, Duoc Vuong, Loi Cong, Son Than, Than Tai, Thanh Hoang, Tho Dia... Particularly for the Village's Tutelary god, every village had one and it was by the people of construction village. Taoism has become an important content in the traditional life of the people, especially in which the worship of the Tutelary god is more concerned...

The promotion of Confucianism of the Le dynasty, inevitably must improve self - sufficient folk spirits. But the imperial court could not create tens of thousands of gods to decentralize. Moreover, it was impossible to impose the gods on the villagers. This work requires the participation of the people. The birth of the village Tutelary is in accordance with the needs and minds of the villagers.

The affection of religion and belief is inevitable due to the phenomena that people cannot explain, but that affection for the Vietnamese people does not speak out but it still contains rational factors, the combination between the emotional and rational elements of Vietnamese thinking have created a difference for the religions that Vietnamese people have come across.

The mix of Chinese-style Tutelary gods and Village's Tutelary gods of Vietnamese people has created a rich and diverse Vietnamese Citadel. This blend clearly shows the continuation and integration of foreign cultures into Vietnamese culture. On the one hand, avoid oppression and assimilation of the enemy; on the other hand, enriching the Vietnamese culture without losing the unique and very unique characteristics of Vietnamese culture.

In the central feudal society exercising the right, the rule of the upper class is entirely through imposition. People, especially farmers, are very hard to resist. The best way is to accept it, but they do not completely mold it according to that imposed opinion. Is there some way to keep my valuable self and still not suppressed by the ruling class? The best way is to integrate foreign religions, adjust them to the common sense of the community, the idea for the part of the poor in society, restructure according to the nationalist mind of Vietnamese people so that reconcile with the ruling class.

The image of Viillage's Tutelary god is continuously added, creating a richness for the village Tutelary system, and at the same time with the development it is the desire to have a better and better life of the Vietnamese village residents.

\subsection{Classification the Village's Tutelary Gods}

By studying the divine relics as well as learning about the worship of the Tutelary gods in villages and communes in Vietnam, we realize that in every village and commune of Vietnam often worship a Village's Tutelary god, there were also two villages, three even five, seven Tutelary gods; However, there was a god master.

Each of the Village's Tutelary god had a divine and divine genius associated with the characteristics, natural conditions and historical circumstances of the village. However, there were cases where many villages worship a Village's Tutelary god, such as Tan Vien god, worshiped by many villages in the former Ha Tay province, although the gods of this god in each locality are different: in the Do village, Tan Vien was worshiped for his gratitude for teaching people to do farming and singing; in Shandong, he was again worshiped by the merit of teaching people to make grass sickles, reaping rice, who taught people to weave baskets from rattan and bamboo to make tools to carry grass, rice...

The Village's Tutelary gods were often worshiped at communal houses and shrines, but sometimes there were a place to worship the village Tutelary god at the temple according to the motif of "Before the god, after buddha". With the viewpoint of "three religious prairies" (three religions of the same origin), many monks and nuns were enlightened as: Tu Dao Hanh meditation teacher (Thay pagoda - Ha Tay old province - Today is Hanoi) was conferred as the Holy Father, to be called the Tu Holy; Khong Lo meditation monk (Keo pagoda - Thai Binh province) was conferred the title of Holy Patriarch, to be called Khong Lo Holy; Hue Tzu meditation monk (Co Tung pagoda - Nam Dinh province), was conferred Duc Bao Trung 
Hung - Linh adored the spirit, calling him the Tu Holy...

In the communal houses, the shrine of the gods had a genealogy, also known as "Ngoc pha". This was a book that records the area of worshiped gods (divine powers). The divine relic was largely collected and drafted by the Dong Cac Dai Hoc Si (Nguyen Binh) in Hong Phuc (1572), the reign of Le Anh Tong king, who was then stationed in Yen Truong, Thanh Hoa province, because the North was under the governing reason of the Mac house. Later on, the director of the secret police, Hung Linh Thieu Khanh Nguyen Hien to copy it on Le Vinh Huu (1735-1739). Some gods appeared in King Tu Duc's reign (1848-1882). The rest of the genealogies to this day, there has been many layers of different information piling up, adding and modernizing the divine relics through repeated or new editions [21].

\subsection{The Ranks of the Village's Tutelary God}

“Gods. Each village served a Village's Tutelary god, sometimes a village worshiped two, three Village's Tutelary gods, a village worshiped five and seven Village's Tutelary gods who known as the Blessed spirit. The spirit has been divided into three categories: Upper god; Middle god; Inferior gods" [8].

The Upper gods: including gods with great merits to the people, with the country, were ordained by the king and established temples such as Tran Hung Dao, Hai Ba Trung, Ly Thuong Kiet, Pham Ngu Lao,... and the angels were widely circulated in humanity about their merits to help people and help the country such as Tan Vien Son Than, Thanh Giong, Lieu Hanh princess, Chu Dong Tu... All these gods had their merit and merit the king ordained as a senior god [15].

The Middle gods: including gods or local officials who openly fill, set up hamlets, have gratitude to the people, sometimes gods that the villagers have long worshiped, whose surname was unknown, or there were the bishop who did not know their name, or the gods with a bit of aura, until the king of the island came to fulfill the dynasty, then the court made Middle god.

The Inferior gods: including gods worshiped by the villagers, although they do not know the divine powers, but also belong to the divine authority. The feudal court followed the villagers and ordained a lower class.

In addition to the above three gods, many villages worship strange gods such as the beggar god in Thu Lan village - Nam Ha province; god of theft in the village of Fur Khe - Thai Binh province; god of feces in Co Nhue village - Hanoi capital; Child god, Ta Dam god... According to the explanation of the folk, these gods, apart from their unusual abilities, were worshiped by the dead at sacred hours. At first due to fear, the villagers worshiped after a long time, they were worshiped to help the villagers dispel risks, to sponsor the existence and development of the village community [16].

\subsection{The Process of Ordination for the Village's Tutelary God}

Along with ancient texts and bibliographies through
Vietnamese feudal dynasties, ordination was seen as a kind of orthodox text of the feudal state. Over time and bombs of war, thousands of titles were still preserved by villages and Vietnamese families as a treasure. Why?

The ordinatio appeared from around the 15th century, under the Le dynasty, which was confirmed by the king's seal with the content of state recognition, while showing the power of court for villages. Along with ancient documents and bibliographies such as Chieu, Chi, Hich, epitaph, genealogy,... ordination was considered as a kind of orthodox legal document of feudal state for gods with support for villages and communes.

The ordained spirit for gods or saints was considered to be the common property of the whole village community so it is often kept at temples, temples and shrines. Many temples and temples throughout the country still retain their style identities.

In the history of the development of Vietnamese feudal dynasties, since the Ly and Tran dynasties, "deity" was due to the "phonetic" of the god. But those gods only "sound" for the kings. But starting from the Le dynasty, because of the Confucian monarchy, the central authority should exercise more power and authority, seize all the power of the whole nation into the hands of the court and social governors to the villages.

Therefore, mentally, "king" for the god of the village (Village's Tutelary god head of the gods in the village), became an imperial official, a "king" on behalf of the local king of the province, was "distributed room "just like the demeanor of the feudal regime. What is different, the task of the Village's Tutelary gods was to manage the "soul" of the villagers, while Ly Truong was responsible for managing the "corpses" of the villagers. Both of them - Village's Tutelary god and Ly Truong had to leave home when working on the king. The communal house that became a minor court was like that.

Thus, according to the old custom, the kings used to conquer the Tutelary gods into three steps: upper - class gods, middle-class gods and lower - level gods, depending on the merits and merits of the gods to the country and the people, with the village. The gods were also considered to be from low to high. If in the time of administering these people, they have been blessed, helping a lot for the material and spiritual life of the people will be conferred and promoted. The promotion of the Tutelary gods was based on the village's fortunes of the merits of the gods. This must be submitted to the court for a specified period of time. Each court promotion sent the king a very good spirit and stored it in the crest of worship at the palace's harem.

\subsection{Places of Worship}

The communal house has been a place of worship and become a spiritual cultural symbol of every Vietnamese native. Every village has been a family, sometimes each village has been a separate house. Communal house to worship the Village's Tutelary god, but at the same time it became a meeting place for village dignitaries, or a place of community activities. All these activities occurred in the family with the witness of the Village's Tutelary god [20]. 


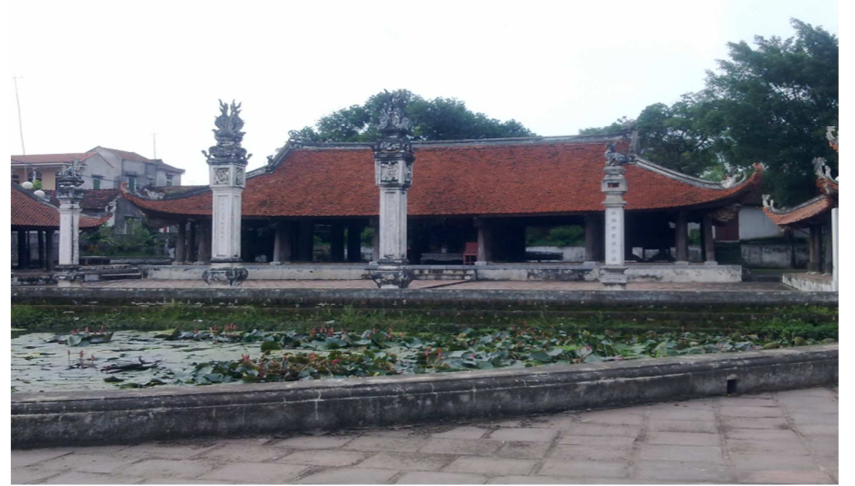

Figure 2. Communal house in the North of Vietnam.

The communal house has been also the place to perform the ceremony of the village of the Village's Tutelary gods. Every year, Village' Tutelary god death anniversary was the most crowded festival day of the village. In the festival days, in addition to doing the work, there were many rituals such as re-enacting the legend of the Village's Tutelary god, sacrifices, palanquin or fun games: fighting martial arts, cockfighting, rice cooking, swimming and brushing swinging, playing human chess, singing cheo, singing performance... The atmosphere has been happy all day and night (there are places two, three days), from the old men, the old lady comes to each child, and most awaits, the most fun had the boys and girls of the same age, this was an opportunity to meet, make friends, confess.

The Northern Delta region of Vietnam is still home to many ancient houses of the country. The temples still preserved today can be named as: Thuy Phieu temple (Ba Vi, Hanoi capital) built in 1531, Lo Hanh temple (Hiep Hoa, Bac Giang provice), Dung temple (1566 - 1577), Dinh temple (Thuong Tin, Hanoi capital) (1581) or Tay Dang temple (Ba Vi, Hanoi capital)... was built in the sixteenth century. According to the researchers, the beautiful and large-scale houses are often built in the historical periods when the socio-economic development and communalism are more and more beautiful, the more beautiful the architecture, the more affirms the position of the village. Folk culture researcher Le Quang Ngoc said: "I have traveled many places, big houses in famous villages are usually located in the center of the village, in a spacious and decent campus. The roads often dodge it to honor the place where the house is located. In villages with such strife, in communal architecture, there are often large columns of columns, the rooms in the communal house are also more spacious".

\section{The Value of the Beliefs of the Village's Tutelary God}

\subsection{Awareness of Gratitude for Those Who Have Contributed to the Village}

The village's Tutelary god was a man who had meritorious services to the villagers: establishing a village, setting up a profession, teaching for the villagers, fighting the enemy, rescuing people... Just like the ancestor worship of the Vietnamese people, worshiping the Village's Tutelary god as abelief, both the morality of the posterity for the predecessor who had merits to the village and the country. If ancestor worship is morality expressing a sense of origin towards the source of the family and lineage, worshiping the Village's Tutelary god is also an honor to the predecessors at the village level.

Every village worships the Village's Tutelary god, each of the Village"s Tutelary god had different origins and merits, "the drums of that village fight themselves, the god of any village of that village worship themselves". Therefore, the village is indispensable for a sacred symbol, guardian god to signal the gathering, strengthening and protecting community development. The worship was derived from the gratitude, the remembrance of the villagers with the meritorious services to the village.

However, perhaps the difference between villages is to worship their own gods, who are both close and sacred to each village, "the people in the village are self-conceived, worshiping themselves. His own Village's Tutelary god like the god of destiny, mainly to ensure rain and wind, bring peace to the community" [17].

\subsection{Community Association}

Beliefs of the Village's Tutelary god play a role in linking the community of people in a limited agricultural territorial community, as a spiritual gathering place for residents. The Village's Tutelary gods witnessed the life of the villagers, gave them the blessings of the people who were hospitable, gentle, and despised to punish those who were evil. There are catastrophes, people often come to pray for god to cover. There is a dreadful job, people often pray for the divine witness to keep it healthy, unjustly punish that person. Everyone in the community always follows the rules and ethics because they always keep in mind that God always monitors the activities of each member of the community. God is also a force to support the people in anti-invasion, quenching natural disasters, epidemics by way of sound. The gods are worshiped by the villagers every year and are ordained by the feudal court after each island experience.

The Vietnamese feudal and selective state for the Village's Tutelary gods aims to unite and mobilize all the strength of the village, commune and ethnic community into one block, and carry out the social management to social facilities. The communal house appeared at the beginning with the function of being the administrative headquarters - the office of the feudal state in the village and commune gradually became a place of worship of the Tutelary gods and a meeting of officials and villagers.

Along with the feudalism of the village and village gods, feudal court conducted the unified management of the country. The village gods became village Tutelary gods. The Village's Tutelary gods with merits to help the king to defeat the invaders and help the people except for natural disasters or epidemics of the court were ordained as the Village's 
Tutelary god. The communal house is not only a place to worship the Village's Tutelary god but also a place where villagers gather when there is a common job, a place of fun for the whole village on festivals. The old house is both the "administrative headquarters" of the village, both the "court" of the commune and the bustling days of the crowd, the courtyard becomes "the stage" and "stage" for activities. Art and culture such as Cheo singing, singing and singing, drum playing, as well as sports activities such as wrestling, lion dance, tug of war, chess playing, rice-blowing competition... For centuries, until the first few decades in the 20th century, the main function of the Northern communal house was still the "big hall of the village" [18].

If ancestor worship is the foundation that unites all family members; then the worship of the Village's Tutelary god is the foundation that binds all members of the village and commune community. Based on the aspirations and wishes of the members of the village converging on the god.

\subsection{Maintain and Preserve the Traditional Cultural Values of the Village and Commune Communities}

The Village's Tutelary god is one of the cultural elements that Vietnamese farmers have created over generations. Associated with the Village's Tutelary god is the village festival - a traditional cultural activity bearing the identity of each locality.

In recent years, in villages have joined each other to restore the festival cultural activities. In the beginning of spring every year, Dong Ky village, Dong Quang commune, Tu Son district (now Dong Ky Ward, Tu Son town), Bac Ninh province held a merit memorial festival for the Citadel of the Emperor Thanh, Diamonds of Hung king. Although it has now abandoned the fireworks, but Dong Ky still holds the ceremony of solemn artillery reception, jubilantly, and in the family still preserves giant artillery with colorful codes, the procession of firecrackers is still crowded and excited thousands of other domestic and foreign tourists.

Each traditional Vietnamese village has its own custom and customs, forming a village custom. In the mind of Vietnamese people, The Village's Tutelary god is the supreme deity, able to cover and witness the entire life of the villagers, protect and bless the villagers to prosper and be healthy. The generations of people continue to grow, but the Village's Tutelary god is still forever, becoming an undeniable witness of a village through floating sinks. The Village's Tutelary god is the supreme commander of the village not only spiritually, but also a part of the material life of the villagers. Therefore, "the worship of the tutelary god is the worship of the village rules, the customs of the village" [18].

Although today, the Village's Tutelary god is no longer suitable for modern society if it remains the same, but the village festival related to the Village's Tutelary god is recurring in many places, bringing excitement and cultural activities to the village. The worship of the Village's Tutelary god, especially the gods, expresses the morality of drinking water, remembering the source of our people, promoting the values of morality, ceremony, meaning,... helping people, especially the young generation, not to be dissolving into the modern cultural rhythm, preserving and promoting cultural traditions, contributing to building an advanced culture but still imbued with national identity.

\subsection{Spiritual Support of the Villagers}

The Village's Tutelage god became a spiritual symbol, a strong spiritual base for the people. Because with them, only gods can help rain and wind to be harmonious, good crops; helping their life more and more stable and prosperous, so the village without the Village's Tutelary god, the village is unsafe.

Although science has evolved today, people still face many obstacles in life such as dangerous diseases, infertility, etc., that medicine must give up. Or as a fire, unexpected natural disasters: earthquakes, tsunamis, floods,... every year robbed people of life. At that time, people must rely on gods, pray for the protection of the gods.

Vietnamese people spent thousands of years building and maintaining the country, throughout that long history, people had to unite together, the sense of community cohesion was formed and developed to combat natural disasters and aggression.

Belief in worshiping the Village's Tutelary god of the Vietnamese people expresses their gratitude and desire to repay the thanks of the next generation to the previous generation, which is handed down from generation to generation, consolidating and sustained. Gratitude plays an intermediary role, adjusts the existence and activities of religious activities to worship the Village's Tutelary god. Gratitude is crystallized from culture [18], becoming the philosophy of the Vietnamese people, teaching people to live in good faith, having a clear mind, knowing how to behave, worshiping ancestors and people with meritorious services to the country. Gratitude in the belief of worshiping the village tutelary gods exists and grows along with the history of the nation, gradually absorbed into the generations of Vietnamese people. Over time, the philosophy of gratitude has not changed, will forever be an eternal value, affirm the longevity of the nation, create a cultural strength in integration and development.

\section{Conclusion}

Thus, "Vietnamese culture is essentially a village culture" [19]. Along with the worship of ancestors, beliefs of the Mother Goddess worship and some other folk beliefs, the belief in the Village's Tutelary god is actually the spirit of gods and gods which plays a role in linking the human community in a territory limited by village bamboos, as a spiritual refuge for village residents. That belief brings Vietnamese colors in essence, no matter how many other elements and cultures it has been absorbed. That is the identity of religious beliefs, which underlies the nation's existence and development for thousands of years. "It is not superstition, not religion (universal). Only bring blessings to farmers, do not cause bad consequences like religious war or 
religious discrimination" [9]. The belief of worshiping the Village's Tutelary gods plays a role in linking the community in the village and commune and expanding to the whole country, to educate the patriotism, humanity, towards good things. Those are extremely valuable cultural and communication values of the nation that today we need to inherit and promote.

Beliefs worship the Village's Tutelary god is the creation of Vietnamese farmers who have been experimented for generations. However, Vietnamese society was in the period of industrialization and modernization, the Vietnamese Emperor's religion no longer played a leading role in the spiritual activities of the village, and it basically no longer existed. Keep the original original. But, the values it brings in the spiritual life of the village residents cannot be denied.

Preserving and promoting cultural heritage is the responsibility of each person and also to contribute to building an advanced Vietnamese culture imbued with national cultural identity. The generations of people continued to flourish, but the Village"s Tutelary god was forever, becoming an undeniable witness of a village through changes of the times

\section{References}

[1] Dai Viet Su Ky Toan Thu. "Noi cac quan ban" edition; Wood edition was carved in the 18th year of Chinh Hoa government. (1697) (translation: 2004). Hanoi: Social Sciences.

[2] Binh, P. K. (1990). Vietnam custom. Hanoi: Information Culture.

[3] Mark, C., \& Engels, Ph. (1995). Complete. Hanoi: National Political.

[4] Van, D. N. (2003). Theory of religion and religious situation in Vietnam. Hanoi: National Political.

[5] Anh, D. D. (1996). Han-Vietnamese dictionary. Hanoi: Social Sciences.

[6] Anh, T. (2005). Worship custom. Hanoi: Youth.
[7] Thinh, N. D., \& Frank Proschan. (Editor, 2005). Folklore some contemporary terms. Hanoi: Social Sciences.

[8] Yang, C. K. (1967). Religion in Chinese Society: A Study of Contemporary Social Functions of Religion and Some of Their Historical Factors. Berkeley and Los Angeles: University of California Press.

[9] Hinh, N. D. (1996). Belief of Village's Tutelarry god of Vietnam. Hanoi: Social Sciences.

[10] Ngoc, P. (2002). Vietnamese Cultural Identity. Hanoi: Literary.

[11] Zito, A. R. (1987). City Gods, Filiality, and Hegemony in Late Imperial China. Modern China: Symposium on Hegemony and Chinese Folk Ideologies Part II. 13: 333-371. JSTOR 189310 - via JSTOR.

[12] Xuyen, L. T. (1994). Viet Dien U Linh. Hanoi: Culture.

[13] Phuc, N. V., \& Hinh, N. D. (2009). Tutelary gods and Thang Long belief - HaNoi. Hanoi: Laodong.

[14] Khanh, N. V. (2001). Vietnam Folk Religion. Hanoi: Ethnic Culture.

[15] Duy, N. D. (2002). Spiritual culture. Hanoi: Information Culture.

[16] Giau, T. V. (1973). The development of Vietnamese thought from the 19th century to the August revolution. Hanoi: Social Sciences.

[17] Sinh, T. D. (Editor, 2017). Ethics drinking water remember source - philosophical and valuable basis in national history. Hanoi: Education.

[18] Tho, N. T. (Editor, 2017). Social ontology about Hieu religion in Vietnam today. Hanoi: Social Sciences.

[19] Vuong, T. Q. (2003). Vietnamese Culture - Exploring and pondering. Hanoi: Information Culture.

[20] Tan, H. V., \& Ku, N. V. (1998). Vietnamese communal house. Vietnam: Ho Chi Minh.

[21] Kham Dinh Dai Nam Hoi dien su le. (1993). Vol 6. Hue: Thuanhoa. 